\title{
INVESTIGATION OF INTAKE OF URANIUM IN DRINKING WATER AROUND CHICKMAGALURE, INDIA.
}

\author{
Manjunatha S. ${ }^{1}$ and $\mathrm{P}$ Venkataramaiah ${ }^{2}$ \\ 'Department of Physics, The Oxford College of Engineering, Bommanahalli, Hosur Road Bangalore-560068, INDIA. \\ ${ }^{2}$ Department of PG Studies, University of Mysore-570009, INDIA \\ Email: manjunatha_s@yahoo.com
}

ABSTRACT

An important route of human intake of uranium and other radionuclides, especially when the general population is considered is by ingestion through drinking water. The present study conducted around Chickmagalure, Karnataka, India. The concentration of uranium in natural waters is generally found to be very low, often being of the order of few parts per billion ( $\mathrm{ppb}$ ). Laser Flourimetry has been used to estimate the uranium concentration in drinking water. Uranium concentrations are found to vary from 0.2 to $27.9 \mathrm{ppb}\left(\mathrm{g} . \mathrm{I}^{-1}\right)$ with a geometric mean of $3.7 \mathrm{ppb}$. The daily intake of uranium by the local population of the study region varies from about 0.8 to $111.6 \mathrm{~g} \cdot \mathrm{d}^{-1}$.

KEYWORDS: Uranium, Radionuclides, Laser Flourimetry

\section{INTRODUCTION}

Uranium is present in all type of rocks, soil and water. Uranium present is either in uranous $\left(\mathrm{U}^{4+}\right)$ or uranyl $\left(\mathrm{U}^{6+}\right)$ form. Uranium occurs most commonly as oxides, hydroxides, phosphates, carbonates, sulphates, arsenates, vanades and silicates [4]. These are derived from the decomposition of uranium minerals like uraninite, pegmatite and pitchblende veins $[9,10]$.

Uranium concentration in water depends on host aquifer rock, the presence of oxygen and complexing agents, chemicals in the aquifer, chemical reactions with ions in solution and the nature of contact between the uranium minerals and the water. The uranium content of natural water may vary from traces to $600 \mathrm{ppb}\left(\mathrm{g} . \mathrm{I}^{-1}\right)$ or more [6]. In the ground and surface water it is found to be about $0.2 \mathrm{ppb}$. Normally concentration of uranium in air is much less than in food and water. Uranium enters the body through drinking water, which contains trace quantities of uranium. According to one estimate food contributed about $15 \%$ of the ingested uranium while drinking water contributed the remaining $85 \%$ to the human population in U.S.A [3]. Many authors reported the concentration of uranium in drinking water using Laser Flourimetry technique $[5,12,13]$.

\section{EXPERIMENTAL PROCEDURE}

Most of the natural waters contain a few ppb of dissolved uranium [4]. Although spectrometers are available and used for the determination of uranium, their accuracy at levels of uranium found in natural waters is low. In the present investigation, Laser Flourimetry has been used to estimate the uranium concentration in drinking water and its detection limit of uranium in water is of the order of a few ppb. It's most serious drawback however is the quenching of uranium fluorescence by many interfering elements like $\mathrm{pH}$, hardness, turbidity etc. It uses a nitrogen laser as the primary excitation source. The measurement is based on the fluorescence of uranium salt under ultra violet excitation. Uranyl salts emit fluorescence that spans the spectral region from 490 to $540 \mathrm{~nm}$ with three characteristic peaks. A fluorescing agent, namely Fluran is used to convert the various Uranyl species present in water into a single form, which has a high and uniform spectral yield. The instrument was calibrated using standard solution in the range of 0.5 to $10 \mathrm{ppb}$ before analysis of normal samples

The drinking water collected and processed as mentioned in Ghoda et al. The sample of water to be tested was filled in a quartz cuvette (cell). The pH of the water sample was adjusted to about and $0.5 \mathrm{ml}$ of Fluran was added to the sample in the cell and mixed thoroughly. The Fluorimeter reading was noted. The same procedure was repeated with the water sample under investigation. The concentration of uranium in the sample is calculated $[5,12]$.

\section{RESULT AND DISCUSSION}

An important route of human intake of uranium and other radionuclides, especially when the general population is considered by ingestion through drinking water. The results are given in Table- 1. Uranium concentrations are found to vary from 0.2 to $27.9 \mathrm{ppb}$ with a geometric mean of $3.7 \mathrm{ppb}$. These values are well within the WHO standard of $30 \mathrm{ppb}$ for drinking water [19].

Lake water was found to be having higher concentration of dissolved uranium than other water bodies. This is probably due to accumulation of suspended particulate, large aquifer contact and water run off from fields under active cultivation where fertilisers (phosphate) have been used [6]. The $\mathrm{pH}$ of lake waters were also found to be higher $(8.0-8.4)$ than other water sources. The higher $\mathrm{pH}$ may be one of the additional reasons for higher dissolved uranium content. With an oxidising environment 
at higher $\mathrm{pH}$ value $(>7)$ solubility of uranium is known to be favored if it is converted to uranyl form $\left(U^{6+}\right)$ [11]. The highest uranium value (27.9 $0.7 \mathrm{ppb}$ and $\mathrm{pH} 8.4)$ was measured at the Magadi, which is very close to the rocky mountain of Uraniferous Quartz Pebble Conglomerate (UQPC) [10].

Underground water was found to contain higher uranium content than municipal supply water. The values for Kalasapura and Devagondanahalli villages were of moderate order at 11.6 and $7.8 \mathrm{ppb}$ respectively. These villages are close to the $\mathrm{U}-\mathrm{QPC}$ region. On the other hand low values of 0.43 and $0.2 \mathrm{ppb}$ were found in Karthekere and Mirle, which are also close to the U-QPC region [9]. While lower contents of the primordial radionuclides where found in the surface soils of Lakya and Lakshmipura, the water of these villages showed higher uranium content. Nearly $55 \%$ of study locations showed uranium content of water to be less than $4 \mathrm{ppb}$.

Table 1. Concentration of Uranium in Water

\begin{tabular}{|c|c|c|c|c|}
\hline $\begin{array}{l}\text { SI. } \\
\text { No }\end{array}$ & Location & $\begin{array}{l}\text { Source } \\
\text { of Water }\end{array}$ & pH & $\begin{array}{c}U \\
\text { Conc. } \\
\text { (ppb) }\end{array}$ \\
\hline 1. & Birur (8) & Bore well & 7.0 & $\begin{array}{l}5.5 \pm \\
0.10\end{array}$ \\
\hline 2. & Birur (4) \# & Lake & 7.1 & $\begin{array}{l}2.0 \pm \\
0.04\end{array}$ \\
\hline 3. & $\begin{array}{l}\text { Chickmagalur, } \\
\text { (7)\# }\end{array}$ & Bore well & 7.2 & $\begin{array}{l}2.4 \pm \\
0.08\end{array}$ \\
\hline 4. & Chickmagalur & Lake & 8.5 & $\begin{array}{l}3.6 \pm \\
0.22\end{array}$ \\
\hline 5. & $\begin{array}{l}\text { Chickmagalur } \\
\text { (4) \# }\end{array}$ & Lake & 7.5 & $\begin{array}{l}1.3 \pm \\
0.02\end{array}$ \\
\hline 6. & $\begin{array}{l}\text { Chickmagalur } \\
\text { ZP (4) }\end{array}$ & Bore well & 7.3 & $\begin{array}{l}5.7 \pm \\
0.15\end{array}$ \\
\hline 7. & $\begin{array}{l}\text { Chickmagalur } \\
\text { Mudigere Road } \\
\text { (5) }\end{array}$ & Bore well & 7.1 & $\begin{array}{l}3.8 \pm \\
0.10\end{array}$ \\
\hline 8. & $\begin{array}{l}\text { Devagondanahal } \\
\text { li village (9) }\end{array}$ & Lake & 8.1 & $\begin{array}{l}6.2 \pm \\
0.16\end{array}$ \\
\hline 9. & $\begin{array}{l}\text { Devagondanahal } \\
\text { li village }\end{array}$ & Bore well & 7.3 & $\begin{array}{l}7.8 \pm \\
0.25\end{array}$ \\
\hline 10. & Kadur (10) & Bore well & 6.8 & $\begin{array}{l}3.2 \pm \\
0.05\end{array}$ \\
\hline 11. & Kadur (8)\# & River & 7.9 & $\begin{array}{l}3.9 \pm \\
0.10\end{array}$ \\
\hline 12. & $\begin{array}{l}\text { Kadur Bus stand } \\
\text { (6) }\end{array}$ & Bore well & 7.3 & $\begin{array}{l}0.62 \pm \\
0.10\end{array}$ \\
\hline 13. & $\begin{array}{l}\text { Kalasapura } \\
\text { village (6) }\end{array}$ & Bore well & 7.2 & $\begin{array}{l}11.6 \pm \\
0.08\end{array}$ \\
\hline 14. & $\begin{array}{l}\text { Karthekere } \\
\text { village (8) }\end{array}$ & Bore well & 7.5 & $\begin{array}{l}0.43 \pm \\
0.02\end{array}$ \\
\hline 15. & $\begin{array}{l}\text { Magadi Kymara } \\
\text { (7) }\end{array}$ & Bore well & 7.7 & $\begin{array}{l}2.3 \pm \\
0.08\end{array}$ \\
\hline 16. & Lakshmipura (6) & Bore well & 7.1 & $\begin{array}{l}6.8 \pm \\
0.23\end{array}$ \\
\hline 17. & Lakya (12) & Bore well & 6.9 & $\begin{array}{c}13.5 \pm \\
0.50\end{array}$ \\
\hline 18. & Magadi (6) & Lake & 8.4 & $\begin{array}{c}27.9 \pm \\
0.7\end{array}$ \\
\hline
\end{tabular}

\begin{tabular}{|c|c|c|c|c|}
\hline 19. & Mirle (8) & Bore well & 7.2 & $0.2 \pm$ \\
\hline 20. & Mundre (10) & Lake & 8.0 & $\begin{array}{l}17.5 \pm \\
0.45\end{array}$ \\
\hline 21. & Mundre (6) & Bore well & 7.0 & $\begin{array}{c}4.9 \pm \\
0.10\end{array}$ \\
\hline 22. & Sakrepatna (6) & Bore well & 7.2 & $\begin{array}{l}0.8 \pm \\
0.09\end{array}$ \\
\hline 23. & Sakrepatna (7) & Well & 7.1 & $\begin{array}{l}1.7 \pm \\
0.11\end{array}$ \\
\hline 24. & Shivapura (5) & Well & 7.8 & $\begin{array}{c}16.3 \pm \\
0.19\end{array}$ \\
\hline 25 & $\begin{array}{l}\text { Uddeboranahalli } \\
\text { (11) }\end{array}$ & Bore well & 7.4 & $\begin{array}{c}0.3 \pm \\
0.02\end{array}$ \\
\hline \multicolumn{4}{|c|}{ Overall $\mathrm{pH}$ range $6.9-8.5$} & $\begin{array}{l}0.2- \\
27.9\end{array}$ \\
\hline
\end{tabular}

ð Municipal Supply, Parenthesis indicates number of samples.

The concentrations of uranium in water measured in this area may be compared with values reported from other places in India as well as outside (Table- 2). The present study shows a general agreement between uranium levels observed in and around Chickmagalur and the values reported in literature from elsewhere.

Table 2. Concentration of Uranium in Waters from Different Environs

\begin{tabular}{|c|c|c|c|c|}
\hline \multirow[t]{2}{*}{ Region } & \multicolumn{2}{|c|}{$\begin{array}{c}\text { Uranium in } \\
\text { water } \\
\left(\mu \mathrm{g} . \mathrm{I}^{-1}\right)\end{array}$} & \multirow{2}{*}{$\begin{array}{l}\text { Analysis } \\
\text { Method/ } \\
\text { Instrumen } \\
\text { tation }\end{array}$} & \multirow{2}{*}{$\begin{array}{l}\text { Refere } \\
\text { nce } \\
\text { no. }\end{array}$} \\
\hline & Range & Mean & & \\
\hline \multicolumn{5}{|c|}{ Indian Scenario } \\
\hline $\begin{array}{l}\text { Chickma } \\
\text { galur, } \\
\text { India } \\
\end{array}$ & $\begin{array}{l}0.2- \\
27.9\end{array}$ & 3.7 & $\begin{array}{l}\text { Laser } \\
\text { Flouri } \\
\text { metry }\end{array}$ & $\begin{array}{c}\text { Prese } \\
\text { nt } \\
\text { Study } \\
\end{array}$ \\
\hline $\begin{array}{l}\text { Mysore, } \\
\text { Karnatak } \\
\text { a }\end{array}$ & $\begin{array}{c}\mathrm{BDL}- \\
67.8\end{array}$ & - & -do- & 12 \\
\hline $\begin{array}{l}\text { Bhatinda, } \\
\text { Punjab }\end{array}$ & $\begin{array}{l}11.7- \\
113.7\end{array}$ & - & $\begin{array}{l}\text { Fissio } \\
\text { n } \\
\text { Track }\end{array}$ & 8 \\
\hline $\begin{array}{l}\text { Amritsar, } \\
\text { Punjab }\end{array}$ & $\begin{array}{c}17.9- \\
20.2\end{array}$ & - & -do- & 8 \\
\hline $\begin{array}{l}\text { Kanpur, } \\
\text { U.P. }\end{array}$ & $2.6-9.9$ & - & -do- & 13 \\
\hline $\begin{array}{l}\text { Allahaba } \\
\text { d, U.P. }\end{array}$ & $0.9-3.8$ & - & -do- & 13 \\
\hline $\begin{array}{l}\text { Jhansi, } \\
\text { U.P. }\end{array}$ & $0.9-6.5$ & - & -do- & 13 \\
\hline $\begin{array}{l}\text { Southwe } \\
\text { st coast } \\
\text { Ganga }\end{array}$ & $0.4-2.7$ & - & -do- & 1 \\
\hline $\begin{array}{l}\text { River, } \\
\text { Himalaya } \\
\text { s }\end{array}$ & $\begin{array}{l}0.9- \\
33.4\end{array}$ & - & -do- & 15 \\
\hline $\begin{array}{l}\text { Jadugud } \\
\text { a, Bihar }\end{array}$ & $0.4-5.0$ & 0.7 & $\begin{array}{c}\text { Radioc } \\
\text { hemic } \\
\text { al }\end{array}$ & 7 \\
\hline $\begin{array}{l}\text { India } \\
\text { (Overall) }\end{array}$ & $\begin{array}{ll}0.6 & - \\
19.2\end{array}$ & - & - & 2 \\
\hline
\end{tabular}


Manjunatha S. et al: Investigation of Intake of Uranium in Drinking Water...

\begin{tabular}{|c|c|c|c|c|}
\hline \multicolumn{5}{|c|}{ World Scenario } \\
\hline China & $\begin{array}{c}0.04- \\
5.3\end{array}$ & - & $\begin{array}{c}\gamma \\
\text { Spectr } \\
\text { ometry }\end{array}$ & 13 \\
\hline Finland & $0.3-4.2$ & - & $\begin{array}{l}\gamma \\
\text { Spectr } \\
\text { ometry }\end{array}$ & 16,18 \\
\hline $\begin{array}{l}\text { Newyork, } \\
\text { USA\# }\end{array}$ & $0.02-0.04$ & 0.03 & - & 6 \\
\hline $\begin{array}{l}\text { Newyork, } \\
\text { USA@ }\end{array}$ & $\begin{array}{l}0.001- \\
0.003\end{array}$ & 0.003 & - & 6 \\
\hline USA & $\begin{array}{c}0.03- \\
7.0\end{array}$ & - & - & 6 \\
\hline USA* $^{*}$ & $\begin{array}{l}0.03- \\
1948\end{array}$ & - & - & 6 \\
\hline
\end{tabular}

]ð: Tap water (Town Supply). @: Deionised water. *: Underground water.

\section{INTAKE OF URANIUM THROUGH WATER}

The principal route of intake of radionuclides by the general population is through ingestion of food and water. There too the water route is more significant than through ingestion of food. Knowing the concentration of the radionuclides in the waters of a region and the rate of consumption of water the intake by the population can be calculated. The average daily intake of water by Indians is about 4 liters $[9,19]$. The daily intake of uranium by the local population of the study region varies from about 0.8 to 111.6 g.d $d^{-1}$. The mean intake works out to $15.6 \mathrm{~g} \cdot \mathrm{d}^{-1}$ or $5.69 \mathrm{mg} \cdot \mathrm{y}^{-1}$.

\section{CONCLUSION}

Higher levels of uranium were found in surface water (Lake Water) as well as in ground water. In general the uranium concentrations could be graded as Lakes $>$ Wells $>$ Bore wells > Municipal supplies. The higher concentration of uranium in Lake Water is due to large aquifer contact and runoff water from fields under active cultivation. The intake of uranium and other radionuclides by the population of the study region is of the same order as the population of other similar regions.

\section{REFERENCES}

[1] Ashvani Kumar, Jojo PJ, and Rajendra Prasad (1994), Level uranium in water from the south west coast of India,Proc. Of $3^{\text {rd }}$ National symposium on Environment, 68-1.

[2] BARC High lights, (1988), 122-3.

[3] Cohtern CR and Lappenbuch WL (1983), Occurrence of uranium in drinking water $n$ US, Health Physics, 45(1), 89-99.

[4] E Eisenbud, $M$ and Gesell T,Environmental Radioactivity, fourth edn., (1997), San Diego: Academic press Inc.
[5] Ghoda A, Esphani JC, Veseky E, Zepeda and Peris Mark, (1990), Determination of uranium in drinking water in US, Health Physics, 45(1), 89-99.

[6] Hess CT, Michel J, Harton TR, Procured HM and Coniglio WA, (1985), The occurrence of radioactivity in public water supply in United States, Health Physics, 48(5), 553-86.

[7] lyangar MAR and Markose PM, (1971), Monitoring of aquating environment in the neighborhood os uranium mills at Jaduguda, Bihar, NSRP, Bombay.

[8] Jaspal Singh L and Singh S,([1995), High uranium contents observed in some drinking waters of Punjab, J. of Radioactivity, 26(3), 217-22.

[9] Manjunatha S,(1999), PhDThesis, Mysore Univ., India.

[10] Manjuantha S, BN Anandaram, L Parmesh and P Venkataramaiah, (1998), Study of environmental radioactivity at the horizon of uranium bearing quartz [ebble conglomerates near Chickmagalur, Radiat, Physics and Chemistry, 51(4), 619.

[11] Myrick TE, Berven BA and Haywood FF, (1983), Determination of concentration of selected radionuclides in surface soils in the US, Health Physics, 45(3), 631-42.

[12] Nagaih N, (1996), Studies in environmental Radiation around Mysore, PhD Thesis, Mysore Univ., India.

[13] Padam Singh NPS, Ameer Azam, Naqvi AH and Srivastava DS, (1999), Uranium content various water samples of Kanpur as determined by Fission Track Technique, Proc. of $4^{\text {th }}$ National Symposium on Environment, 201-4.

[14] Panziquiang, Yang and Guo Minguiang, [1988], Natural radiation and radioactivity in China, Rad. Protec.Dosimetry, 24(1/4), 29-8.

[15] Singh NP, Surinder Singh and Vivek HS, (1987), Uranium and radon conc. In Ganges water of UP Himalayas-some preliminary results, Indian J. Pure and Appl. Physics, 25, 87-9.

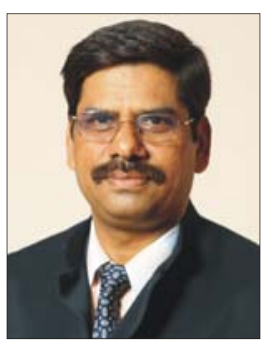

Dr.Manjuantha $S$. is a professor in the Department of Physics, Oxford college of Engineering, Bangalore. He hasve 23 years of teaching experience with 12 publication in National and International journals. His area of research are in Nuclear and Environmental Physics. 